\title{
Oplysning og universalhistorie
}

\author{
Af Knud Michelsen
}

Om Grundtvigs rolle i Ove Korsgaard: Kampen om lyset. Dansk voksenoplysning gennem 500 år, København 1997.

Der var flere, der i forbindelse med Anne Wivels film om Søren Kierkegaard fra 1995 slog ned på det paradoks eller den ironiske pointe, at filmen byggede på et seminar på Testrup Højskole. Selve filmens raison d'être skyldtes m.a.o. Grundtvig. Og ikke nok med det. Alle filmens deltagere, herunder Kierkegaard, blev på denne måde aktører inden for rammerne af et grundtvigsk livsog folkeoplysningsprojekt!

Set på baggrund af Ove Korsgaards bog »Kampen om lyset « fra sidste år er paradokset dog mindre slående. Ifølge ham har højskolen netop bevæget sig fra national-folkelig oplysning til at sætte den enkeltes personlige udvikling $\mathrm{i}$ fokus, og hvad er da mere oplagt end at gøre filosoffen for »Hiin Enkelte« til livs- og folkeoplyser? I sin bog nævner Korsgaard ganske vist knap nok Kierkegaard, men anfører dog et citat fra C.E. Jensen og F.J. Borgbjergs kæmpeværk »Socialdemokratiets Aarhundrede«, hvor det hedder: »I Modsætning til Kierkegaards aristokratiske Tilbagetrukkenhed er Grundtvigs Væsen en bred Folkelighed, som driver ham midt ud i det offentlige Livs Brænding og gør ham til Politiker.« Her er den traditionelle modsætning intakt, ligeså modsætningen mellem Grundtvig og de to socialdemokraters ankermand, Karl Marx. Ingen af disse modstillinger skulle senere vise sig holdbare. Fra 1960'erne begyndte sammentænkningen af Grundtvig og Kierkegaard og fra 1970'erne forsøgene på at forene Grundtvig og Marx.

Med murens fald i 1989 henvistes Marx til historiens skrotbunke, og man kunne fristes til at mene, at det bør gå Grundtvig på samme måde. Også han knyttede sig stærkt til en kollektivistisk ideologi, som i samtiden og især efter nederlaget i 1864 blev en samlende kraft, men som i dag står for fald, nemlig det nationale. I vores på en gang individualistiske og globale tidsalder er det svært at se det nationale som andet end nostalgi eller opium for fremmedfjendske højrekræfter, og hvad skal vi da med en Grundtvig med al hans bragesnak om danskhed fra top til tå? Kierkegaard, jo, ham har vi stadig meget at lære af, men Grundtvig, må ikke også han stedes til hvile på de store, men sammenbrudte fortællingers kirkegård?

Ikke ifølge Korsgaard. Lige så klart han fremanalyserer Grundtvigs stigende understregning af det nationale grundlag for den folkelige oplysning, lige så klart afviser han, at Grundtvigs indsats og betydning skulle være begrænset hertil. Det er da også tydeligt, at højskolen som idé er langt rummeligere end det, grundtvigianerne fik ud af den. Det viser ikke blot dens moderne udvikling, men også dens afsmitning på andre voksenuddannelser. Det løser 
imidlertid ikke så meget problemet, som det skærper det. For hvis højskolen har udviklet sig til en institution, der kan rumme hvad som helst, fra brætsejlads til seminarer over Kierkegaard, fører den så ikke lige så vel til opløsning som til oplysning? Har højskolen ikke svigtet sin primære opgave, hvis den i stedet for at bidrage til samfundets sammenhængskraft forstærker den rådende individualisering? Korsgaard stiller spørgsmålet, men i stedet for at give et entydigt svar udkaster han en række scenarier for højskolens fremtidige udvikling. Dem skal jeg senere vende tilbage til. Forinden er det nødvendigt at gå ind på Korsgaards omtale af den Grundtvig, som for ham ikke har mistet sin aktualitet. Det viser sig overraskende nok at være den Grundtvig, der står bag ideen om en "universalhistorisk Vidskab«. Korsgaard skriver:

»Grundtvig er kendt for at være idémand til folkehøjskolen. Men i virkeligheden er højskolen kun en del af et uhyre ambitiøst program. På skoleområdet havde han en vision om et universitet, hvor det universelle $\mathrm{i}$ verdslig forstand skulle være udgangspunktet. Grundtvig ville nemlig etablere et skolesystem, der byggede på to søjler: en national og en universel. Den ene skulle bære folkehøjskolen, den anden universitetet. Mellem dem skulle der både være spænding og vekselvirkning. Kort sagt skulle folkehøjskolen bygge på folkestammen og være en skole for folkelig oplysning, mens universitetet skulle være stedet for oplysning om menneskelivet i sin helhed. Universitetet skulle være »eet aandeligt Værksted», hvor man med forenede kræfter stræbte mod det, der er af altomfattende, almen art, mod det universelle. Og det skulle man gøre ved »at bearbeide hele den menneskelige Kundskabs-Kreds til Livets Tarv«.«

Det sidste udtryk, »Livets Tarv«, viser forbindelsen til højskoletanken. Det var jo præcis dette kriterium, den europæiske videnskabelighed og $\emptyset$ vrige bogormelærdom ifølge Grundtvig ikke opfyldte. Ved at producere viden frem for oplysning svigtede den sin egentlige opgave, ikke mindst fordi den samtidig manglede et menneske- og historiesyn, der kunne give mening til indsamlingen af data. I den forbindelse citerer Korsgaard med rette de berømte ord fra indledningen til Nordens Mythologi, 1832:

»Mennesket er ingen Abekat, bestemt til først at efterabe de andre Dyr og siden sig selv til Verdens Ende, men han er en mageløs, underfuld Skabning, i hvem guddommelige Kræfter skal kundgiøre, udvikle og forklare sig giennem tusinde Slægter, som et guddommeligt Experiment, der viser, hvordan Aand og Støv kan giennemtrænge hinanden og forklares i en fælles guddommelig Bevidsthed."

I denne formulering ligger ikke blot Grundtvigs menneske- og historiesyn sammenfoldet, men også hans universitet. Det er nu Korsgaards pointe, at "universitetet er kronen på værket i Grundtvigs skoleprogram«, men at »de universelle sider af hans oplysnings- og dannelsestanker blev trængt i baggrunden af den selv samme nationale bevægelse, han var med til at fremme." Ud over sin primære opgave - den at redegøre for dansk voksenoplysning gennem 500 år - har Korsgaard en ikke særlig skjult dagsorden, der går ud på, 
at disse universelle sider kunne danne grundlag for en fremtidig udvikling af højskolen. I hvert fald indgår den 'universelle' Grundtvig centralt i det tredje af de føromtalte scenarier, der alle tager sigte på at begrænse tendensen mod individualisering. Mens det første (det Ebbe Reichske) er at fastholde og styrke bevidstheden om den nationale enhedskultur og det andet (det Ejvind Larsenske) er at se højskolen som lokalsamfundets skole, skriver Korsgaard om det tredje:

»Den tredje udviklingsmulighed (...) er at se højskolens opgave i et universal-historisk perspektiv, der her mod slutningen af det tyvende århundrede har fået et globalt indhold. Det lokale liv udspiller sig i stigende grad i en global verden. Højskolens opgave bliver at kaste lys over det personlige, lokale og nationale liv - et globalt lys. En sådan udvikling af højskolens idégrundlag vil ligge i forlængelse af Grundtvigs universitetstanker. (...) Tiden synes moden til at lade sig inspirere af de skoletanker hos Grundtvig, der ikke blev realiseret, nemlig hans universitetstanker. Om end folkelig-national oplysning for Grundtvig var udgangspunktet, så opfordrede han »danskheden« til at forholde sig åben, »for ei at gaae Glip ad det Almeen-menneskelige, hvori naturligviis alt Folkeligt omsider skal finde sit Maal og sin Forklaring.«

Som man vil se, er intet udelukket i dette scenarie. Det personlige eller individuelle, det lokale, det nationale - alle er de med, dog ikke som selvberoende helheder, men som dele af en global eller universel helhedsforståelse. Faren i dag er, at det individuelle som før det nationale bliver selvtilstrækkeligt. Det er den fare, som det universalhistoriske perspektiv skal sikre imod.

Så vidt Korsgaards fors $ø$ g på at reaktualisere Grundtvig. Hvorvidt det har nogen fremtid for sig, må tiden vise. Man kan jo håbe, at bogen vil give anledning til den nødvendige debat om højskolens idégrundlag og identitet, som foreløbig overskygges af indbyrdes konkurrence og $\emptyset$ konomiske slagsmål. I mellemtiden kan der så være grund til at se nærmere på selve ideen om en universalhistorie, ikke så meget for at spørge, om den lader sig realisere inden for højskolens rammer som for at undersøge ideens bæredygtighed i sig selv. Kort sagt: Er det i dag ikke blot muligt at hævde et begreb om universalhistorie, men også et begreb om universalhistorie på grundtvigske præmisser?

Jeg deler spørgsmålet op i to, for der er ingen tvivl om, at svaret på det første spørgsmål er et ja. Det viser fx den fornyede interesse for Kants og Hegels universalhistoriske udkast, bl.a. hos den amerikanske økonom Francis Fukuyama i hans bog "Historiens afslutning og det sidste menneske«, 1992. Man kan imidlertid ikke uden videre herfra slutte til, at så må også Grundtvigs begreb om universalhistorie have aktualitet. Vanskeligheden ligger $i$, at hans universalhistoriske syn helt ligger inden for rammerne af en kristen eskatologi. Målet for historien er intet mindre end menneskets sandhed om sig selv, løsningen af dets gåde, ikke som hos Kant og Hegel eller for den sags skyld Fukuyama opnåelsen af bestemte politisk-konstitutionelle mål. Derfor er mennesket hos Fukuyama ved historiens afslutning da heller ikke kommet til 
forståelsen af sig selv en hårsbred nærmere. Det er blevet anerkendt, men ikke erkendt.

På den anden side medfører denne forskel så også, at forholdet mellem universalhistorie og videnskab (oplysning) bliver helt centralt hos Grundtvig, men igen bestemt af de kristne forudsætninger. En »universalhistorisk Vidskab« skal ganske vist bidrage til at løse menneskets gåde, men den endelige "forklaring " er identisk med tidernes ende. Som Korsgaard anfører, er den kristne frelseshistorie overordnet den verdslige universalhistorie og - må det tilføjes - må nødvendigvis være det, for gåden ligger $i$ mennesket og kan derfor ikke løses af mennesket selv.

Det er i dette lys, hele Grundtvigs insisteren på det folkeligt-nationale skal ses. På dette niveau, hvor det drejer sig om, hvad han kalder det naturlige menneske, kan han opretholde en klar skelnen mellem kirke og skole, tro og oplysning. Det er langt vanskeligere, når det gælder hans ideer om universalhistorisk vidskab. Her er kristendommen nødvendigvis inkluderet, og spørgsmålet er derfor, om ikke Grundtvig så rigtigt ved at satse på det folkeligtnationale projekt. Det var sandt nok en begrænsning af hans oprindelige ambitiøse program, men med kolossal historisk virkning. Samtidig er det værd at notere sig, at denne satsning netop forudsætter det universalhistoriske syn. Det er jo ikke tilfældigt, at det er i Danmark, opvækkelsen skal ske, for netop Danmark havde for Grundtvig som »Historiens Palæstina« på det tidspunkt sin særlige rolle at spille - i et universalhistorisk perspektiv.

Forestillingen om den rolle kan ikke genskabes, og det betyder så også, at jeg kan have mine tỵivl om, hvorvidt forudsætningerne for at gennemføre Korsgaards scenarie for højskolen er til stede i dag. Derimod er jeg ikke i tvivl om, at højskolen nu som før vil spille en vigtig rolle som ramme om den debat, der føres i samfundet, ligesom dens aktiviteter og fag fortsat vil afspejle samfundets udvikling. Det hænger som før sagt sammen med skoleformens enestående smidighed, frihed og rummelighed, som for mig at se også er dens egentlige styrke.

Til sidst kan jeg ikke lade være med - med et sidelys til Korsgaards seneste udgivelse »En orm - en gud«, 1997 - at advare mod tendensen til at forbinde begreber som universalhistorisk vidskab, holisme, kosmologi. Selv om Korsgaard udmærket er klar over forskellene og fx betoner, at Grundtvig ikke var holist, er det dog den sammenhæng, han tænkes ind i. Langt mere interessant forekommer det mig at genoverveje forholdet mellem universalhistorie og kristendom. Det er i tanken om historien som den gradvise udfoldelse af kristendommens »forklaring «, at Grundtvig har fremtiden for sig. 